\title{
Reengineering of the Construction Companies Based on BIM-technology
}

\author{
TetyanaHoncharenko ${ }^{1}$, Yuri Chupryna ${ }^{2}$, Iryna Ivakhnenko ${ }^{3}$, Miroslava Zinchenco ${ }^{4}$, Tetiana Tsyfra ${ }^{5}$ \\ ${ }^{1}$ Department of Information Technology, Kyiv National University of Construction and Architecture, Ukraine, \\ iust511@ukr.net \\ ${ }^{2}$ Department of Management in Construction, Kyiv National University of Construction and Architecture, Ukraine, \\ chupryna_yura@ukr.net \\ ${ }^{3}$ Department of Management in Construction, Department of Information Technology, Kyiv National University of \\ Construction and Architecture, Ukraine,d2605610@ukr.net \\ ${ }^{4}$ Department of Economics, Faculty of Civil Engineering, Kyiv National University of Construction and Architecture, \\ Ukraine, kmb_knuba@ukr.net \\ ${ }^{5}$ Department of Construction Economics, Kyiv National University of Construction and Architecture, Ukraine, \\ tatena.c@ukr.net
}

\begin{abstract}
The article is devoted toreengineering of the construction companies based on BIM-technology. The analysis of BIMprocesses implementing in construction companies is carried out. The main effects from the using on the word experience example are indicated. The structure of management of real estate objects and interconnection of BIM-management models are presented. The significance of objects operation phase and its relationship with the processes of design, construction and liquidation are determined. The study identifies the advantages and difficulties in the implementation of BIM-technology in an enterprise throughout the life cycle of a construction project. An important aspect is that the BIM-model carries information about the construction object at all stages of its lifecycle. There are three investment directions for the transition of an enterprise to a management system based on the BIM technology: reengineering of business processes of the enterprise and management system; transformation of the organizational structure in terms of staff composition and qualifications; formation of supporting infrastructure. The integration of information flows between participants and stages of an investment and construction project requires a new look at the project and its lifecycle as a whole and the same approach to digitalization and BIM-management.
\end{abstract}

Key words: BIM,PLM, reengineering of business processes, construction enterprise, management system.

\section{INTRODUCTION}

The development of innovative activity of enterprises in the construction industry today is at a relatively low level. Organizations that carry out innovative activities make up no more than $10 \%$ of the total, at the time when in developed countries this indicator tends to $60 \%$, in other Eastern European countries this indicator is $25 \%$.
Many scientists consider the need for innovative development of enterprises in the construction industry with further technological renewal in their scientific works [1-3]. The authors of [4-7] note such a need for the formation of competitiveness in a strategic perspective due to increased global competition in the construction services market, acceleration of innovation and technological development and reindustrialization of the world economy.

Construction engineering is a progressive organizational scheme aimed at increasing the productivity of the construction industry through project-oriented and scientifically based methods of organizing construction production, as well as improving the technology of construction of objects through the introduction of scientific developments [8].

Having analysed the domestic and foreign experience of enterprises in investment and construction activities [9-11], it can be argued that in the Ukrainian economy. There is a tendency to borrow foreign experience in the implementation of long-term construction projects by concluding an agreement with one company for the entire range of services from project development, construction, operation and subsequent disposal, i.e. throughout the entire lifecycle of theconstructionobject.

To improve the efficiency of all stages of the object's lifecycle, it is necessary to improve the theoretical and practical aspects of engineering activities for lifecycle contracts based on the theory of simulation and the functional method using artificial intelligence and BIM technologies [12].

In modern conditions of instability of the foreign policy and economic environment, only those engineering companies are competitive that has unique competencies and technologies, as well as qualified worthy paid personnel [13-15].

The construction of a model of an engineering scheme for organizing construction for a complex life cycle based on the interaction of the construction organizer and contractors is carried out taking into account a variety of initial parameters:

- availability of time and cost constraints of the project; 
- the required volumes of resource provision;

- indicators of production capacities of contractors;

- indicators of available material, technical and labour resources, information on construction conditions;

- intensity and uniformity of resource consumption (financing);

- operating and other costs [16].

BIM technology is a modern approach to design, construction and operation. It allows combining various software products and tools, which allows modeling much cheaper, simplifies the visualization of the future object [17].

The transition of the industrial and civil construction industry to a higher level of competitiveness [18]in many countries of the world is associated with the creation of full-fledged BIM models.

The object of this article is BIM modeling as a technology for increasing the competitiveness of enterprises in the construction industry. Study of issues related to the use of BIM in construction, elucidation and clarification of the essence of BIMtechnology with the determination of the positive and negative aspects of its implementation.

Based on the results obtained from research, it can be said that when using BIM technologies, investors have increased confidence in construction projects. A study by Autodesk [19] provides the following results:

- technical faults are detected on time, due to this, the cost is reduced by $10 \%$;

- project implementation time is reduced by $7-15 \%$;

- the accuracy of estimated calculations increases by $3 \%$;

- the development of construction estimates can be reduced by almost $80 \%$;

- reduced defects and construction waste by $30 \%$;

-it becomes possible to more accurately assess the effectiveness and targeted spending of budget funds.

Table 1 shows the results of studies of the implementation of information modeling technologies, which indicate an improvement in a number of performance indicators:
- contributes to the reduction of construction and operation costs by $30 \%$;

- reduces errors in design documentation up to $40 \%$;

- up to 50\% reduces the project implementation time;

-6 times reduces the time for checking the model;

-4 times reduces planning budget errors;

- up to $90 \%$ reduces the time of coordination and approval;

- reduces construction time by $10 \%$;

- reduces design time by $20-50 \%$.

The study shows the dynamics of BIM efficiency growth for start-up companies and companies already entrenched in the construction market.

Also, the consulting company "McGraw Hill Construction" [20] conducted a survey among companies in the construction industry and found out what benefits they received with the introduction of BIM. Thus, the study showed the following results: $41 \%$ of the surveyed companies noted a reduction in the number of errors after the introduction of the technology. In turn, $35 \%$ and $32 \%$ drew attention to improving communication between managers and designers and improving the company's image, respectively. A more complete list of research results can be seenon Figure 1.

Nevertheless, despite all of the above, BIM technology, in addition to all the advantages, has certain disadvantage. Experts identify the following difficulties in implementation:

- retraining from CAD-design to BIM software product;

- the interaction of departments when working in BIM technologies takes a long enough time to get used to;

- high price category for the purchase of the corresponding software products;

- limited BIM managers who are ready to train entire staff and organize the transition to BIM technologies.

All these problems put the introduction of BIM technologies in Ukraine into a difficult position. A key indicator of a company's maturity in using BIM technologies is the level of technological and organizational changes as part of the transition to BIM.

Table 1:Advantages of BIM implementationin construction companies

\begin{tabular}{|c|l|c|c|}
\hline \multirow{2}{*}{ № } & \multicolumn{1}{c|}{ Advantages } & \multicolumn{2}{c|}{ Companies: } \\
\cline { 3 - 4 } & & "beginners" & "experienced" \\
\hline 1 & Increase in profits & $10 \%$ & $45 \%$ \\
\hline 2 & Support for the duration of specific work chains & $12 \%$ & $50 \%$ \\
\hline 3 & Reducing the number of changes in the project & $25 \%$ & $75 \%$ \\
\hline 4 & Repeated agreements with former clients & $20 \%$ & $60 \%$ \\
\hline 5 & New service offer & $28 \%$ & $72 \%$ \\
\hline 6 & New business marketing to new customers & $27 \%$ & $73 \%$ \\
\hline 7 & Increase in staff productivity & $36 \%$ & $65 \%$ \\
\hline
\end{tabular}




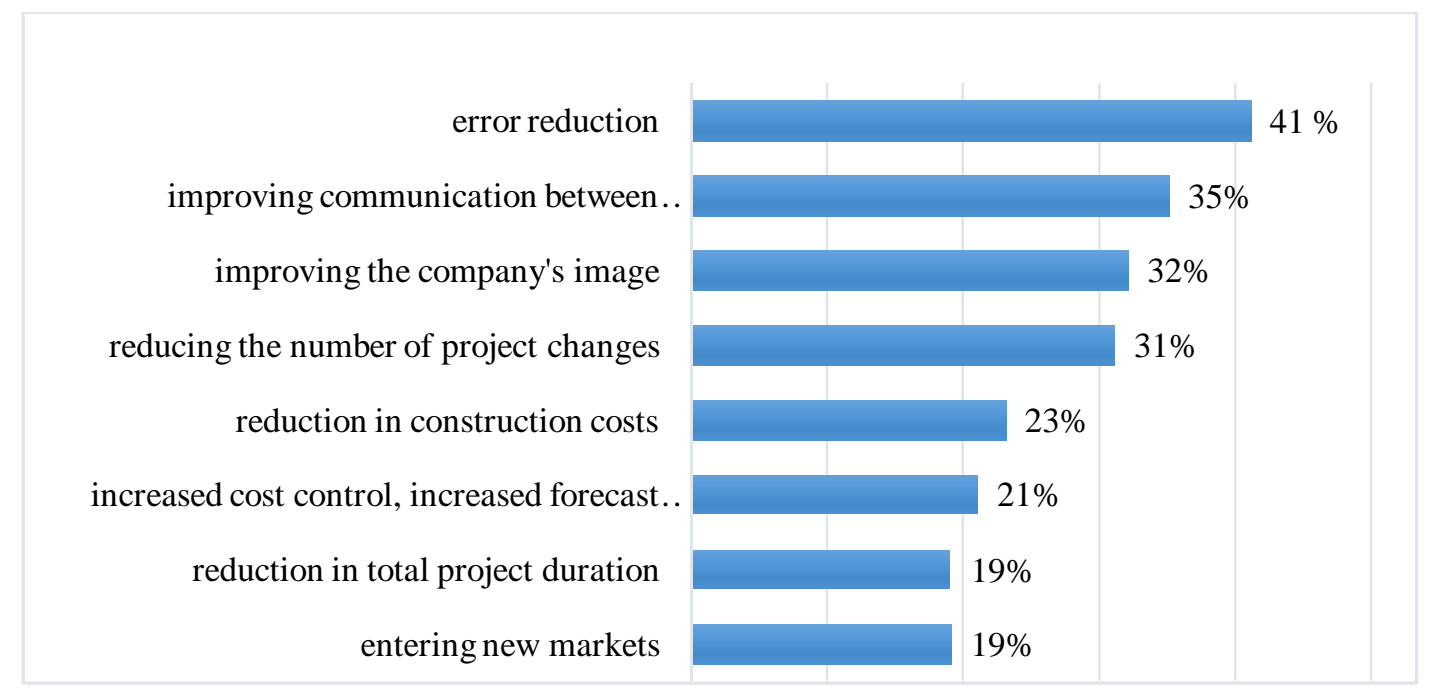

Figure 1: Results of BIM implementation. Source: [20]

\section{RESEARCH}

Information modeling technologies are constantly evolving. This led to the creation of technologies 4D modeling, 5D modeling, 6D modeling, Product Lifecycle Management, Multi-D modeling - PLM and other similar technologies. They help to intensify innovation processes and act as a basic condition for the development of enterprises in the construction industry.

The informational saturation of the model is important, which in the result allows obtaining comprehensive data about the design object. To do this, each participant in the design process must enter data about the object within its own section: architectural, structural, water supply and sewerage, heating and ventilation, electrical equipment, construction organization project, and so on. At the same time, all participants work with the same design data and, accordingly, in the event of a change in project solutions, they change for all project participants. An important aspect is that the BIM-model carries information about the construction object (Figure 2) at all stages of its lifecycle (Figure 3). Thus, a unified hierarchy of data storage is being developed, universal for each specialist and allowing to take into account the specifics of each section of the design and each stage of the object's life cycle. The result is structured data storage, lack of inconsistency and duplication of information.

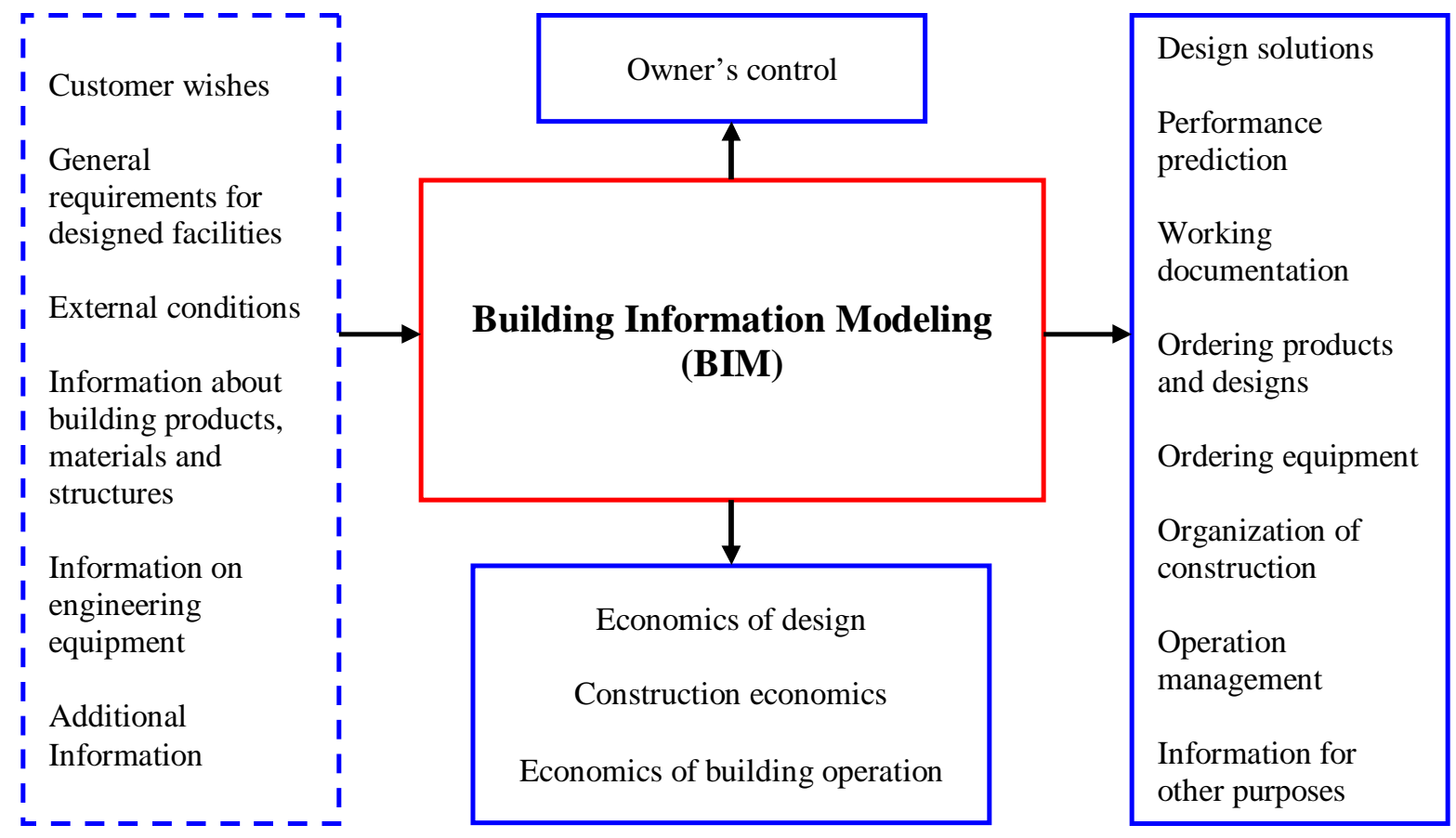

Figure 2: Information flows in the BIM model 4168 


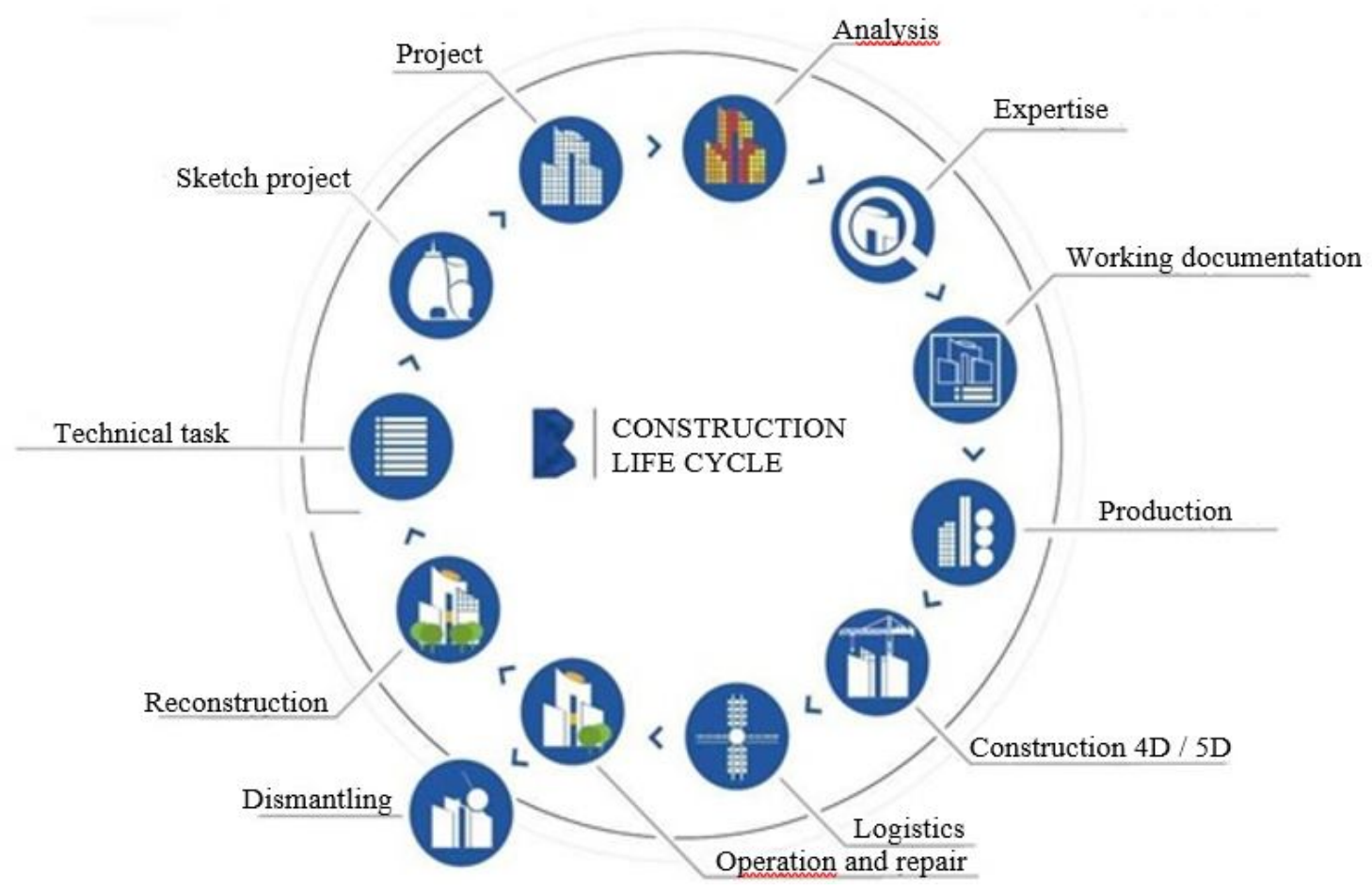

Figure 3: Lifecycle of a construction object.Source: [20].

A complex computer model that describes object and construction process is the result of BIM modeling. This simulation brings together all information into a single database. This allows getting up-to-date project documentation and visualization.

BIM-technology is not perfect, it does not work automatically, and it does not replace humans. Moreover, BIM-technology requires a lot of professionalism and a comprehensive understanding of the process from the participant in the construction process. However, at the same time, BIM brings a creative component to work, makes human work more efficient.

Based on the considered conditions of effective introduction of BIM-technologies in activity of the enterprise, it is possible to allocate tree basic organizational tools thatare presented on Figure 4:

. 1) reengineering of business processes of the enterprise and management system;

2)reorganization of the organizational structure in terms of staff composition and qualifications;

3) formation of supporting infrastructure.

The introduction of new technology is to move to a new level in the development of production processes, and therefore primarily related to the issue of economic efficiency. Thus, when assessing the feasibility of implementing information modeling technologies, it is necessary to take into account the costs of all types. At the transition stage in the implementation of BIM-technologies, the key stage is the reengineering of business processes of the enterprise. This stage sets the vector of all subsequent changes, determines the basic set of requirements for the material and technical base, as well as the organizational management structure of the company. In this regard, there is a redistribution of costs so that the bulk of them fall on the reengineering of business processes. As part of the evaluation of investments in the process of transition to BIM-technology, all costs are estimated in cash. However, there is a need to convert qualitative information and time indicators, and in this case, it is advisable to resort to expert evaluation of data.
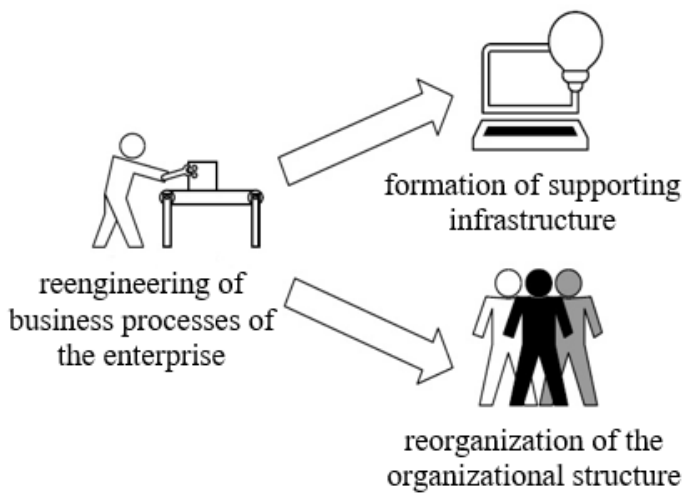

Figure 4: Basic organizational tools for implementing BIM-processes

The transition to information modeling technologies is a set of interconnected processes, and investments in the project of implementation of BIM-technologies are formed from a set of investments in all three areas, presented on Figure 5. Obtaining a reliable cost estimate for the implementation of the project implementation of BIM-technologies is possible through a systematic analysis of the three areas of investment. Only after such an analysis is the feasibility of determining the effectiveness of the company's transition to information modeling technology. 


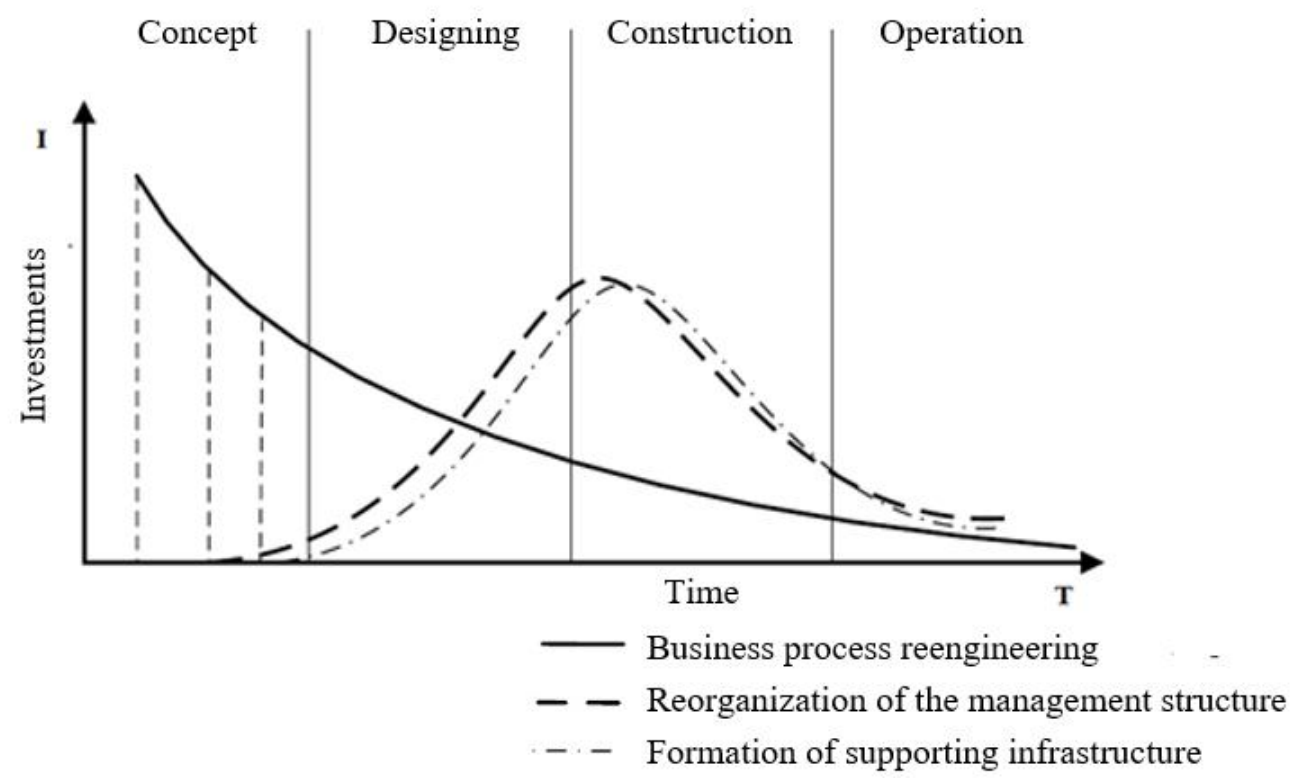

Figure 5: The cost structure of the enterprise at different levels of BIM-processes

\section{RESULTS}

Figure 6 presents a scheme for attracting BIM specialists for reengineering the company's business processes at different stages of the lifecycle.

The BIM-manager should appear at the beginning of the process of implementing information modeling technologies. At the initial levels of maturity of BIM-processes in the company, the manager is actively involved in the development of work processes, standards and templates of the company. In the future, supports the information model, maintains it up to date, as well as forms training programs and training of employees.

It is recommended to connect BIM-masters during the design process using information modeling technologies. The key task of the BIM-master is the technical support of the information model from the creation of means of entering information into the general data environment to the implementation of expert support for users of BIM-content.

The BIM-coordinator is responsible for ensuring the integrity of the information model by integrating the results of the work of specialists in related specialties according to the approved rules and standards of the company.

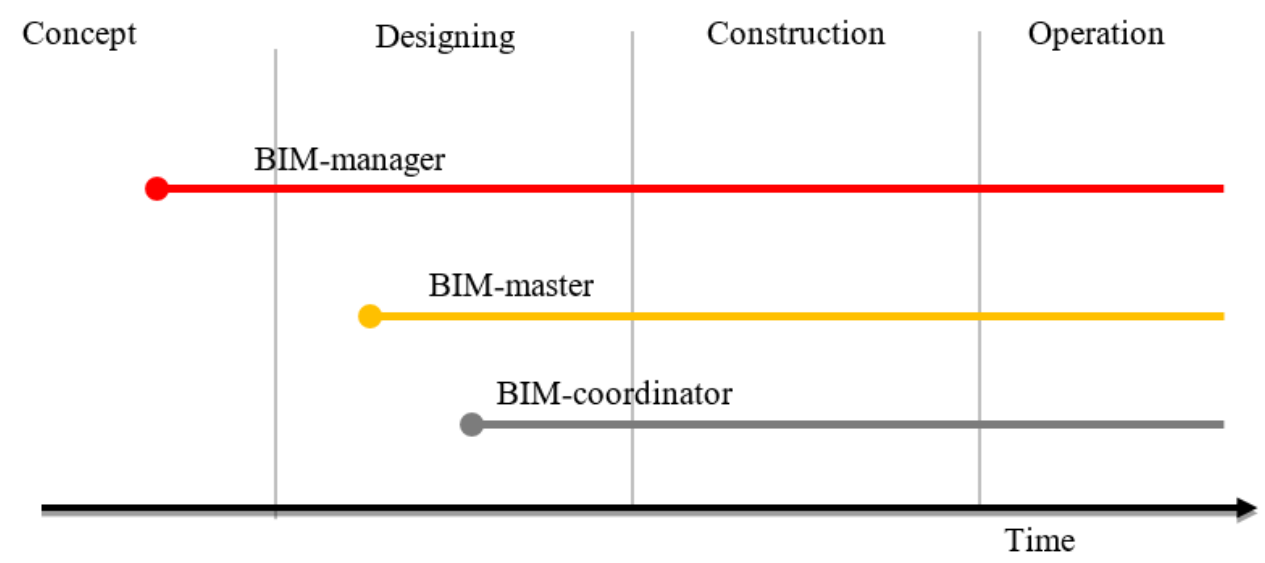

Figure 6: Involvement of BIM specialists for reengineering the company's business processes at different stages of lifecycle 
It is necessary to transfer all specialists of the organization to the new technology to achieve the maximum effect from the transition to information modeling technology of the company. Modernization and improvement of existing tools in the company have to already be performed. At this stage, it is necessary to replace the existing approach to solving the company's problems to innovative through training. It is important to keep in mind that the reduction of labour productivity in the early stages is an inevitable phenomenon (Figure 7), which with effective management of learning processes will be replace by growth. Thus, the choice of educational technologies is one of the determining factors influencing the effectiveness of the transition to BIM-technology.

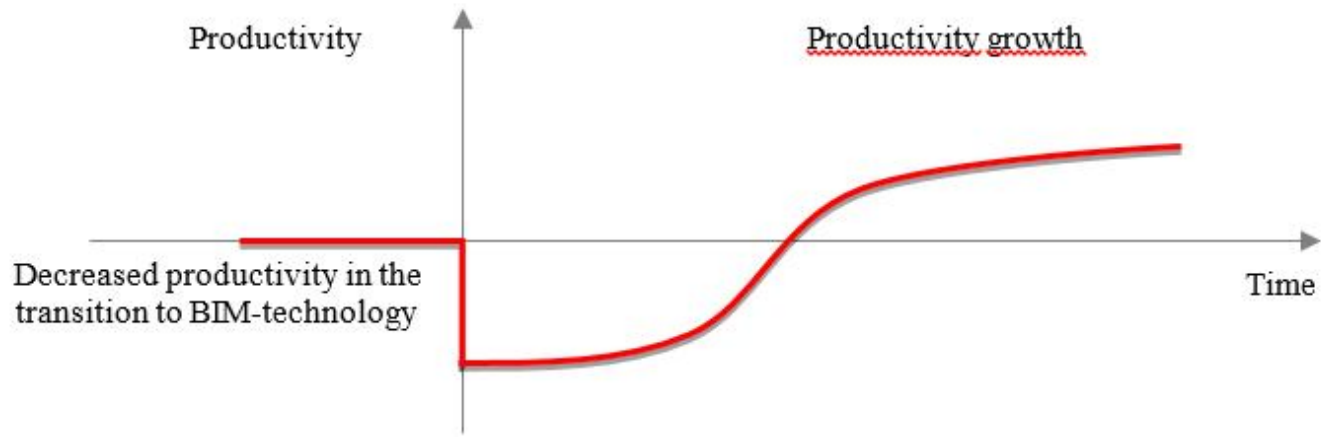

Figure 7: Changes in productivity during the transition to BIM-technology

\section{CONCLUSION}

BIM is a technology that allows achieving great competitive advantages in the construction industry through the optimization of all processes in the development of a comprehensive computer model that describes both the object and life cycle processes from conceptual design to disposal of the object. This simulation combines all the information into a database. This allows you to get up-to-date project documentation and visualization.

The introduction of BIM will significantly improve the performance of the enterprise, increase global competitiveness, control the facility at all stages of its life cycle. BIM-technology will help achieve the goals set in the strategy of innovative development of the construction industry, which, in turn, will increase the efficiency of the industry and improve the quality of construction products.

BIM-technology is not the name of a computer program or family of programs, it is a methodology of modeling and organization, which takes into account all the parameters and data related to the life cycle of the construction object (future object of operation) and ranging from land purchase costs to subsequent monthly costs utility costs and so on. All these data with technical and economic indicators and other characteristics form a single integrated information model, in which the change of one parameter leads to the automatic recalculation of all related data.

\section{REFERENCES}

1. Wong, J., Wang, X., Li, H., Chan, G., Li, H. A review of cloud-based BIM technology in the construction sector in Journal of Information Technology in Construction, Volume 19, 2014, pp. 281-291.
2. http://www.itcon.org/data/works/att/2014_16.content.06 672.pdf

3. R. Miller, D. Strombom, M. Iammarino, B.Black. The Commercial Real Estate Revolution:Nine Transforming Keys to Lowering Costs, Cutting Waste, and Driving Change in a Broken Industry, John Wiley \& Sons, 2009, 352 p.

4. A Report for the Government Construction Client Group Building Information Modelling (BIM). Working Party Strategy Paper. March 2011.

5. A.Volkov, P.Chelyshkov, D.Lysenko. Information management in the application of BIM in construction. Stages of construction, Procedia Engineering, 2016, no. 153, pp. 833-837.

6. V.V. Talapov. Vvedenie v informatsionnoemodelirovaniezdaniy [Introduction to Building Information Modeling (BIM)] Saratov: Profobrazovanie, 2017. (in Russian).

7. V.V. Talapov. Tekhnologiya BIM: sut' iosnovyvnedreniyainformatsionnogomodelirovaniyaz daniy[BIM Technology: Essence and Implementation Bases of Building Modeling]. Moscow, DMK press Publ., 2015, 410 p. (In Russian)

8. M.G.Korol. BIM:informatsionnoemodelirovanie -tsifrovoyvekstroitelnoyotrasli [BIM: information modeling - the digital age of the construction industry]. Stroymetall. (9). 2014, pp.26-30. (in Russian).

9. S.S.Bachurina, T.S. Golosova. Skvoznoe BIM-proektirovanie - osnovavozvratainvestitsiy [End-to-End BIM Design as a Basis for Return on Investment].Sovremennyeproblemupravleniyaproektam i v investitsionno-stroitel'noysfereiprirodopol'zovanii :sborniktrudov $5-y$ Mezhdunarodnoynauchno-prakticheskoykonferentsii (g. Moskva, 10 aprelya 2015 g.) [Contemporary Problems of 
Project Management in Investment and Construction Sphere and Nature Management: Collection of Works of the 5th International Science and Practice Conference (Moscow, April 10th, 2015)]. Moscow, IPO «Grifi K» Publ., 2015, pp. 13-18. (In Russian)

10. T. Marchuk, D Ryzhakov, G. Ryzhakova, S. Stetsenko. Identification of the basic elements of the innovation-analytical platform for energy efficiency in project financing, Investment Management and Financial Innovations, Volume 14, Issue 4, 2017, pp. 12-20, http://dx.doi.org/10.21511/imfi.14(4).2017.02

11. R.Miller, D.Strombom, M.Iammarino, B.Black. The commercial real estate revolution: nine transforming keys to lowering costs, cutting waste, and driving change in a broken industry, John Wiley \& Sons, 2009. $352 \mathrm{p}$.

12. V. Mihaylenko, T. Honcharenko, K. Chupryna, Yu. Andrashko, S. Budnik. Modeling of Spatial Data on the Construction Site Based on Multidimensional Information Objects in 'International Journal of Engineering and Advanced Technology (IJEAT)', ISSN: 2249-8958 (Online), Volume-8 Issue-6, August 2019, Page No. 3934-3940. URL:

https://www.ijeat.org/wp-content/uploads/papers/v8i6/F 9057088619.pdf

13. O. Terentyev, S. Tsiutsiura, T. Honcharenko, T. Lyashchenko. Multidimensional Space Structure for Adaptable Data Model in 'International Journal of Recent Technology and Engineering (IJRTE)', ISSN: 2277-3878 (Online), Volume-8 Issue-3, September 2019, Page No. 7753-7758. URL: https://www.ijrte.org/wp-content/uploads/papers/v8i3/C 6318098319.pdf

14. A. Kuchansky, Y. Andrashko, A. Biloshchytskyi, O. Danchenko, O. Ilarionov, I. Vatskel, T. Honcharenko. The method for evaluation of educational environment subjects' performance based on the calculation of volumes of M-simplexesin Eastern-European Journal of Enterprise Technologies, 2 (4-92), pp. 15-25

URL:http://journals.uran.ua/eejet/article/download/1262 $87 / 125235$

15. D.Chernyshev, I.Ivakhnenko, M.Klymchuk.The organization of biosphere compatibility construction: Justification of the predictors of building development and the implementation prospects in International Journal of Engineering and Technology(UAE), Part $.27 \quad$ (3),2018, $\quad$ Pages 584-586,https://www.sciencepubco.com/index.php/ijet/a rticle/download/14594/5943

16. V. Savchenko, V. Akhramovych, A.Tushych, I. Sribna, I. Vlasov. Analysis of Social Network Parameters and the Likelihood of its Construction in International Journal on Emerging Trends in Engineering Research, 8(2), April 2020, Pages 271-276, https://doi.org/10.30534/ijeter/2020/05822020

17. I. Ulbieva, K.Uzhakhov, A.Tsechoeva, A.Dzangieva, M.Uzhakhov.The Construction Technology of Preschool Institutions: Eco-Friendly and Fire-Resistant Materials in International Journal on
Emerging Trends in Engineering Research, 8(4), April 2020, Pages 1227-1231, https://doi.org/10.30534/ijeter/2020/46842020

18. M. Ahmad,T. Sinelnikova,S. Mustafa, V.Lyashenko. Features of the Construction and Control of the Navigation System of a Mobile Robot in International Journal on Emerging Trends in Engineering Research, 8(4), April 2020, Pages 1445-1449 https://doi.org/10.30534/ijeter/2020/82842020

19. K.I.Kyivska, S.V.Tsiutsiura, M.I.Tsiutsiura, O.V.Kryvoruchko, A.V.Yerukaiev, V.V.Hots.A study of the concept of parametric modeling of construction objects in International Journal of Advanced Research in Engineering and Technology Volume 10, Issue 2, 2019, Pages 636-646

20. Information modeling of industrial and civil construction objects. Autodesk. [Electronic resource]. URL: https://damassets.autodesk.net/content/dam/autodesk/w ww/campaigns/BTT-RU/BIM\%20for\%20buildings_Aut odesk.pdf

21. The Business Value of BIM for Construction in Major Global Markets Icn-solutions. Retrieved from https://www.icn-solutions.nl/pdf/bim_construction.pdf 